\title{
TRADE PROTECTION IN CHINA'S AUTOMOBILE AND TEXTILE INDUSTRIES AND ITS IMPACT ON TRADE LIBERALISATION
}

\section{KAI}

China has become a significant player in the international market and foreign trade has assumed an important role in China's economic development. In 1997, China's total foreign trade volume was recorded as US $\$ 325$ billion, an increase of 15 per cent on the previous year, ranking the country as the tenth largest trader in the world. In the same year, China's trade surplus was approximately 4.4 per cent of GDP.

With such a large external orientation, it is essential for China to investigate the impact of global trade liberalisation before further integrating itself into an increasingly open international trading system. The impact on the major domestic industrial sectors, including both labour-intensive and capital or technologyintensive sectors is of particular importance.

Generally speaking, China has a comparative advantage in the labour-intensive sectors, so production in those sectors will expand following the adoption of a more open trade regime. Although China has less advantage in capital and technology-intensive sectors, it still needs to foster some of these important industries in the light of its large population and domestic market, the limited world market in labour-intensive goods, and the tendency towards deterioration in the terms of trade for developing economies.

In order to calculate the impact of trade liberalisation on both sectors, the Chinese textile and automobile industries are chosen as examples of each of these sectors and the level of trade protection is measured in each sector. The costs of trade protection - or in other words the welfare of trade liberalisationis also investigated. A caveat is necessary: due to data limitations, the investigation should be considered preliminary, and further work remains to be done in the area. 


\section{MEASURING TRADE PROTECTION IN THE AUTOMOBILE AND TEXTILE SECTORS}

\section{FORMS OF PROTECTION OF CHINA'S AUTOMOBILE TRADE}

Non-tariff trade protection measures and their characteristics. Since the 1980s, the major measures adopted by China in this regard have included

- regulation of approval for automobile imports. For example, in 1985 China stipulated that all imports of luxury cars, luxury jeeps, luxury tourist automobiles and common sedans were forbidden except those approved by the State Council

- regulation of types of imports

- inclusion of automobile imports in national plans

- limits to the issue of licences

- implementation of quotas on automobile imports

- implementation of an import licensing system

- collection of fees and taxes in a manner different from those levied on domestic automobiles

- imposition of import inspection by customs

- nomination of special automobile import units

- selection of special automobile import harbours.

China's restrictions on automobile imports have been greatly relaxed. Now the main non-tariff measures in place are import quotas and licence administration. Tariff protection measures. In the past few years, tariffs on imported automobiles have been characterised by

- declining tariff rates. Tariffs on cars have been further lowered by an average of 80 per cent since 1 October 1997. Tariffs on other vehicles and parts have followed the same trend

- narrowing the categories of automobiles that enjoy exempt or reduced tariffs, and reduced tariff rates

- the frequent application of preferential tariff rates

- a system whereby special purpose motor vehicles enjoy the lowest tariff rate, with the rate for trucks higher than that for motor vehicles, large buses higher than trucks, medium-sized buses higher than large buses and mini-buses and sedans highest in the hierarchy of imported automobiles.

\section{MEASURING CHINA'S AUTOMOBILE TRADE PROTECTION}

The price comparison method is usually employed internationally when describing the degree of trade protection. It involves

- comparison of retail prices of the same imports in the domestic market and world market (excluding factors that cannot be compared, such as freight, insurance and distribution charges among enterprises in different countries) 
- comparison between the CIF price of imports and the factory-gate prices of domestically-made commodities of similar quality

- comparison between the CIF value and price, including the CIF and price of trade protection measures on imports.

Due to the lack of price data in the international market and the difficulties in selecting domestically-made commodities that are of the same quality as imports, a third means is tentatively applied to estimate the degree of trade protection in the Chinese automobile industry, as follows. Suppose

$\mathrm{ATP}=$ the level of automobile trade protection

$\mathrm{ACIF}=\mathrm{CIF}$ value of imported automobiles

$\mathrm{APV}=$ price variation due to trade protection measures, then $\mathrm{ATP}=(\mathrm{ACIF}+\mathrm{APV}) / \mathrm{ACIF}$.

Generally speaking, trade protection measures that result in variations in automobile price can be divided into two types: taxation including tariffs, and non-taxation protection measures including import quotas and licensing systems. Thus,

$$
\begin{aligned}
& \mathrm{ATP}=\mathrm{ATP} 1+\mathrm{ATP} 2 \\
& \mathrm{ATP} 1=\text { level of taxation protection } \\
& \mathrm{ATP} 2=\text { level of non-taxation protection. }
\end{aligned}
$$

MEASURING THE DEGREE OF PROTECTION IN THE FORM OF TAXES AND FEE COLLECTION

Retail price constituents of imported automobiles in the domestic market are analysed as follows: retail price $=$ the CIF price of imported automobiles + other pre-sale charges

1 tariffs tariff volume $=$ CIF price of imported automobiles $\times$ tariff rate $=$ $\mathrm{ACIF} \times$ tariff rate

2 consumption tax consumption tax volume $=(\mathrm{ACIF}+$ tariff volume $) \times$ consumption $\operatorname{tax}$ rate / ( 1 - consumption tax rate)

3 value-added tax

Value-added tax on imported automobiles can be divided into two components: the value-added tax levied through customs, labeled value-added tax 1 .

Value-added $\operatorname{tax} 1=(\mathrm{ACIF}+$ tariff volume + consumption tax volume $)$ $\times$ value-added tax rate;

and the value-added tax levied by taxation bodies when the imported automobiles are sold. This is labeled value-added tax 2 [cf. expense (4)] 
4 other importation expenses, including commodity inspection charges, bank charges, foreign trade agency charges and sundry charges for port entry

The four expenses mentioned above plus the CIF of the imported automobiles equal the total cost of automobile imports.

5 other expenses incurred between the time automobiles are declared at customs and the time they are sold, including

a) the operational and management expenses of enterprises engaged in the distribution of imported automobiles, including management expenses, interest, storage expenses and the profits taken by the distribution enterprises. It is generally stipulated that such expenses should be less than or equal to the import cost of the automobile $\times$ $6.5 \%$. Expenses $(1)+$ import cost of the automobile $=$ automobile sales cost

b) value-added tax $2=$ (automobile sales cost - automobile import cost) $\times$ value-added tax rate

c) urban maintenance construction tax and instruction surcharges $=$ value-added tax $2 \times 8 \%$

d) automobile purchase surcharges $=$ (automobile sales cost + expense $b+$ expense $c) \times 10 \%$

The sum of expenses (1) to (4) including the CIF of imported automobiles makes up the theoretical sale price of the imported automobile, including taxes in the domestic market (that is, without taxation exemption).

As the CIF of imported automobiles is theoretically the same as the factorygate prices of those made domestically without trade protection, automobile trade protection by means of taxation is actually reflected in the price discrepancy between the sale price of imported automobiles (including taxes) in the domestic market where the tariff rate and the commodity inspection charge equal zero, and the sale price where the tariff rate and the commodity inspection charge do not equal zero. Suppose,

$\mathrm{a}=$ tariff rate on imported automobiles

$\mathrm{b}=$ consumption tax rate on imported automobiles

$\mathrm{c}=$ value-added tax rate on imported automobiles

$\mathrm{d}=$ commodity inspection charge (generally $\mathrm{D}=\mathrm{ACIF} \times 0.003$ )

$\mathrm{e}=$ other expenses excluding commodity charges in expenses (3) (generally $\mathrm{E}=4.5 \% \times$

ACIF)

tariff volume $=\mathrm{TT}=\mathrm{ACIF} \times \mathrm{a}$

consumption tax volume $=\mathrm{CT}=(\mathrm{ACIF}+\mathrm{TT}) \times \mathrm{b} /(1-\mathrm{b})$

value-added tax $1=\mathrm{AT}=(\mathrm{ACIF}+\mathrm{TT}+\mathrm{CT}) \times \mathrm{c}$

operational and management expenses $=(\mathrm{ACIF}+\mathrm{TT}+\mathrm{CT}+\mathrm{D}+\mathrm{E}) \times 6.5 \%$ 
The discrepancy between the sale price of imported automobiles in the domestic market (including taxation) where the tariff rate and commodity inspection charge equal zero, and that where the tariff rate and commodity inspection charges do not equal zero can be calculated as

$$
\mathrm{APV} 1=\operatorname{ACIF}[\mathrm{a}(1+\mathrm{bc}+\mathrm{c}) /(1-\mathrm{b})+0.3 \%] \times 1.1847
$$

Thus, the degree of automobile taxation trade protection can be expressed as

$$
\mathrm{ATP} 1=\mathrm{APV} 1 / \mathrm{ACIF}=[\mathrm{a}(1+\mathrm{bc}+\mathrm{c}) /(1-\mathrm{b})+0.3 \%] \times 1.1847
$$

In the light of such a formula and the 1996 edition of the catalogue of customs tariffs and customs taxation, the level of China's automobile taxation trade protection can be estimated (Table 8.1).

\section{MEASURING THE DEGREE OF PROTECTION IN FORMS OTHER THAN TAXES AND FEES}

When non-taxation protection measures such as import quotas and licensing systems are implemented, the domestic automobile industry is protected, since

\begin{tabular}{|c|c|c|c|c|}
\hline Auto types & $\begin{array}{c}\text { Tariff rate } \\
\text { (a) }\end{array}$ & $\begin{array}{l}\text { Consumption } \\
\text { tax } \\
\text { (b) }\end{array}$ & $\begin{array}{l}\text { Value-added } \\
\text { tax } \\
\text { (c) }\end{array}$ & $\begin{array}{c}\text { Tax } \\
\text { protection rate } \\
\text { (ATP1) }\end{array}$ \\
\hline Heavy-duty trucks 1 & 30 & 0 & 17 & 42 \\
\hline Heavy-duty trucks 2 & 50 & 0 & 17 & 70 \\
\hline Medium trucks & 50 & 0 & 17 & 70 \\
\hline Light trucks & 50 & 0 & 17 & 70 \\
\hline Dumping trucks & 15 & 0 & 17 & 21 \\
\hline Buses & 60 & 0 & 17 & 84 \\
\hline Medium buses 1 & 90 & 3 & 17 & 130 \\
\hline Medium buses 2 & 90 & 5 & 17 & 133 \\
\hline Mini-buses 1 & 100 & 3 & 17 & 144 \\
\hline Mini-buses 2 & 100 & 5 & 17 & 147 \\
\hline Mini-buses 3 & 120 & 5 & 17 & 177 \\
\hline Sedans 1 & 100 & 3 & 17 & 144 \\
\hline Sedans 2 & 100 & 5 & 17 & 147 \\
\hline Sedans 3 & 100 & 8 & 17 & 153 \\
\hline Sedans 4 & 120 & 8 & 17 & 183 \\
\hline Jeeps 1 & 100 & 3 & 17 & 144 \\
\hline Jeeps 2 & 100 & 5 & 17 & 147 \\
\hline Jeeps 3 & 120 & 5 & 17 & 177 \\
\hline Derrick cars 1 & 10 & 0 & 17 & 14 \\
\hline Derrick cars 2 & 20 & 0 & 17 & 28 \\
\hline Ambulances & 20 & 0 & 17 & 28 \\
\hline Concrete mixers & 25 & 0 & 17 & 35 \\
\hline Arithmetic mean & 71 & 3 & 17 & 104 \\
\hline
\end{tabular}

Table 8.1 Protection in the form of taxes and fees for automobiles (per cent)

Source: Customs Statistics Yearbook, 1996. 
these measures do not directly add to the cost of imported automobiles, they limit the quantity. Nevertheless, due to limitations, it is still difficult to measure the degree of protection in any standardised way. To get a rough idea of the current level of non-taxation protection in the automobile trade, the key domestic distributors of automobiles have been investigated and the CIF and sale price (including taxation) on some imported automobiles have been compared with the real domestic retail price. On the basis of the analysis of the cost of imported automobiles, the assumption can be made that the difference between the real sale price and the sale price with taxation included is the result of non-taxation protection measures. Thus, the level of non-taxation protection on some imported automobiles can be roughly calculated (Table 8.2 ).

\section{FORMS OF PROTECTION IN CHINA'S TEXTILE TRADE}

Tariff trade protection measures

- Nominal tax, which has been high, has dropped sharply in recent years. In 1997, the overall tariff level was 17 per cent, whereas the average textile tariff level dropped to 17.1 per cent (Table 8.3).

- The structure of textile tariffs shows that the tariff rate has risen steadily and progressively with growth in the processing trade. An example of

Table 8.2 Level of non-tax protection of selected imported automobiles

\begin{tabular}{|c|c|c|c|c|}
\hline Name & $\begin{array}{c}\text { CIF } \\
\text { (US\$) }\end{array}$ & $\begin{array}{c}\text { Tax-included } \\
\text { price } \\
(10,000 \text { yuan })\end{array}$ & $\begin{array}{c}\text { Domestic retail } \\
\text { price } \\
(10,000 \text { yuan })\end{array}$ & $\begin{array}{c}\text { Non-tax } \\
\text { protection } \\
\text { degree }(\%)\end{array}$ \\
\hline Honda 1.6 & 14000 & 28.74 & 29.50 & 6.55 \\
\hline Ford Tempo 2.2 & 9000 & 18.47 & 21.50 & 40.50 \\
\hline Chrysler Neon & 12000 & 24.63 & 29.60 & 49.87 \\
\hline Daewoo Espero 2.0 & 8000 & 16.42 & 21.50 & 76.47 \\
\hline Corsica 2.2 & 12000 & 24.63 & 25.80 & 11.72 \\
\hline Honda Accord 2.0 & 15000 & 30.79 & 34.50 & 29.79 \\
\hline Honda Accord 2.2 & 18000 & 36.95 & 40.05 & 20.75 \\
\hline Daewoo Cielo & 7500 & 15.40 & 19.40 & 64.33 \\
\hline Toyota Camry 2.2 & 18000 & 36.95 & 38.00 & 7.03 \\
\hline Crown 3.0 & 23000 & 48.25 & 49.30 & 5.48 \\
\hline Hyundai 2.0 & 12000 & 24.63 & 31.50 & 68.94 \\
\hline Hyundai 3.0 & 15000 & 31.47 & 34.00 & 20.32 \\
\hline Mitsubishi Jeep & 15000 & 30.79 & 36.00 & 41.84 \\
\hline Kamaza DumpingTruck & 17000 & 17.09 & 31.00 & 98.56 \\
\hline Kamaza Truck & 26000 & 36.61 & 41.00 & 20.33 \\
\hline
\end{tabular}


the operation of the tariff system in 1996 shows that the tariff rate for fibre materials was 10.3 per cent, 17.6 per cent for yarn, 29.1 per cent for textile fabrics and 41.8 per cent for garments.

- At present, the highest levels of tariff protection are found in the chemical fibre and garment industries which are in their infancy.

- The best feature of the Chinese system is that the actually applied tariff rate is low. The applied tariff rate for imported textiles is, on average, only 2.2 per cent. This is mainly because 90 per cent of imported textile products are for the processing trade, which is duty free (Table 8.4).

Table 8.3 China's textile import tariff rates structure

\begin{tabular}{|c|c|c|c|c|}
\hline Material & Degree of processing & $\begin{array}{c}\text { Tariff number } \\
(\%)\end{array}$ & $\begin{array}{l}\text { Basic rate } \\
\text { rate }(\%)\end{array}$ & Favourable \\
\hline \multirow[t]{3}{*}{ Silk type } & $\begin{array}{l}\text { Material } \\
\text { (including preliminary } \\
\text { processing) }\end{array}$ & $5001-5003$ & 54.30 & 8.10 \\
\hline & Yarn & $5004-5006$ & 72.50 & 15.00 \\
\hline & Fabrics & 5007 & 100 & 30.00 \\
\hline \multirow[t]{3}{*}{ Wool and other } & $\begin{array}{l}\text { Material } \\
\text { (including preliminary } \\
\text { processing) }\end{array}$ & $5101-5105$ & 29.40 & 12.80 \\
\hline & Yarn & $5106-5110$ & 52.20 & 20.00 \\
\hline & Fabrics & $5111-5113$ & 100 & 35.00 \\
\hline \multirow[t]{3}{*}{ Cotton type } & $\begin{array}{l}\text { Material } \\
\text { (including preliminary } \\
\text { processing) }\end{array}$ & $5201-5203$ & 13.20 & 7.20 \\
\hline & Yarn & $5204-5207$ & 30.60 & 13.30 \\
\hline & Fabrics & $5208-5212$ & 59.40 & 22.00 \\
\hline \multirow[t]{3}{*}{$\begin{array}{l}\text { Textile fibres from } \\
\text { other plants }\end{array}$} & $\begin{array}{l}\text { Material } \\
\text { (including preliminary } \\
\text { processing) }\end{array}$ & $5301-5305$ & 18.90 & 6.50 \\
\hline & Yarn & $5306-5308$ & 37.10 & 12.30 \\
\hline & Fabrics & $5309-5311$ & 55.00 & 23.00 \\
\hline \multirow{3}{*}{$\begin{array}{l}\text { Chemical fibre } \\
\text { filament yarn }\end{array}$} & Yarn & $5401-5406$ & 46.50 & 21.40 \\
\hline & Fabrics & $5407-5408$ & 100 & 44.20 \\
\hline & $\begin{array}{l}\text { Material } \\
\text { (including preliminary } \\
\text { processing) }\end{array}$ & $5501-5507$ & 40.30 & 17.10 \\
\hline \multirow{2}{*}{$\begin{array}{l}\text { Chemical fibre } \\
\text { abort yarn }\end{array}$} & Yarn & $5508-5511$ & 65.70 & 23.40 \\
\hline & Fabrics & $5512-5516$ & 100 & 41.30 \\
\hline Various material & Garments \& & 61,62 & 90.30 & 41.80 \\
\hline Various material & Other textile & $58,60,63$ & 80.40 & 35.80 \\
\hline Various material & Other textile & $56,57,59$ & 61.60 & 32.00 \\
\hline \multicolumn{5}{|c|}{$\begin{array}{l}\text { Note: Basic rate refers to the concession base on which China re-entered GATT negotiations, and tha } \\
\text { used by China and other signatories participating in the WTO. }\end{array}$} \\
\hline \multicolumn{5}{|c|}{ Source: Customs Statistics Yearbook, 1994.} \\
\hline
\end{tabular}


Table 8.4 Import trade structure of textile products and their applied tariff rate, 1994 (per cent)

\begin{tabular}{|c|c|c|c|c|c|}
\hline & \multirow[b]{2}{*}{ Total } & \multicolumn{3}{|c|}{ Structure } & \multirow[b]{2}{*}{ Barter } \\
\hline & & $\begin{array}{l}\text { General } \\
\text { trade }\end{array}$ & $\begin{array}{l}\text { Material- } \\
\text { supplied } \\
\text { processing }\end{array}$ & $\begin{array}{l}\text { Material- } \\
\text { imported } \\
\text { processing }\end{array}$ & \\
\hline Share in total textile imports & 99.1 & 8.8 & 62.6 & 26.7 & 1.0 \\
\hline $\begin{array}{l}\text { Average real } \\
\text { implemented tariff rate }\end{array}$ & 2.23 & 23.1 & - & - & 20.0 \\
\hline \multicolumn{6}{|c|}{$\begin{array}{l}\text { Notes: 1. Import structure is taken from the report conducted under the auspices of the Department of } \\
\text { Trade, China Textile Association by Wang Lie. } \\
\text { 2. The average real implemented tariff rate is calculated from the Customs Tariff Rule, } 1996 . \\
\text { Source: Customs Statistics Yearbook, } 1994 \text {. }\end{array}$} \\
\hline
\end{tabular}

Non-tariff protection measures include

- import quotas

- import licences

- authorised agencies

- a textile import registration system.

\section{MEASURING CHINA'S TEXTILE TRADE PROTECTION}

Tariff protection in the textile sector. Tariff rates for textile products have sustained several cutbacks in recent years, but this figure is still behind what was required of China by American and European states during the Uruguay Talks. The full requirements place great pressure on the future development of China's textile industry. An examination of China's import structure for textile products and its pattern of trade shows that China's actual tariff rate is zero because over 90 per cent of imported textile products are brought into the country for the processing trade (mainly raw materials for textiles, yarn and a small proportion of textile fabrics). Therefore the current high nominal taxation only affects garments and other textile products imported by way of general trade transactions and barter trade.

Because of the low volume that general trade and barter trade occupy in textile imports, it can be concluded that the actual tariff rate for China's textile imports is significantly lower than average nominal tariff rates.

Non-tariff protection in the textile sector. Degree of non-tariff protection $=$ exfactory price of products of the same kind (quality) / (CIF price of imported products $(1+$ tariff rate $)) \times 100 \%$.

In the above formula, the ex-factory price of domestic products already includes value-added taxes, so to facilitate a comparison between the two prices, 
TRADE PROTECTION IN CHINA'S AUTOMOBILE AND TEXTHE INDUSTRIES

Table 8.5 Textile price comparison of imported and domestic products (yuan)

\begin{tabular}{|c|c|c|c|c|c|c|c|}
\hline Type & $\begin{array}{l}\text { Import } \\
\text { (c.i.f) }\end{array}$ & $\begin{array}{l}\text { Tariff } \\
\text { rate }\end{array}$ & $\begin{array}{c}\text { Real } \\
\text { implem- } \\
\text { ented } \\
\text { tariff rate }\end{array}$ & $\begin{array}{c}\text { Domestic } \\
\text { producer } \\
\text { price }\end{array}$ & $\begin{array}{c}\text { Comparable } \\
\text { producer } \\
\text { price }\end{array}$ & $\begin{array}{c}\text { Degree } \\
\text { of non- } \\
\text { tariff } \\
\text { protection } \\
n^{1}(\%)\end{array}$ & $\begin{array}{c}\text { Degree } \\
\text { of non- } \\
\text { tariff } \\
\text { protection } \\
\mathrm{n}^{2}(\%)\end{array}$ \\
\hline Calico & 5.8 & 45 & - & 8.6 & 7.4 & -12.0 & 27.6 \\
\hline $\begin{array}{l}\text { Medium-length } \\
\text { textile cloth }\end{array}$ & 11.1 & 80 & - & 15.0 & 12.8 & -36.0 & 16.4 \\
\hline Cotton yarn & 18.0 & 25 & - & 22.1 & 18.9 & -16.0 & 5.0 \\
\hline Woollen yarn & 43.2 & 50 & - & 72.5 & 62.0 & -4.3 & 43.5 \\
\hline \multicolumn{8}{|c|}{$\begin{array}{l}{ }^{1} \mathrm{CIF} \text { (yuan) is calculated as } \mathrm{CIF} \text { (dollars)*exchange rate }(8.4) .{ }^{2} \text { Tariff rate and applied tariff rate are } \\
\text { expressed as two types such as the rate for general trade and that for the processing trade. }\end{array}$} \\
\hline \multicolumn{8}{|c|}{$\begin{array}{l}\text { Customs Statistics Yearbook (1994); China Industrial Products Yearbook (1994); author's } \\
\text { calculations. }\end{array}$} \\
\hline
\end{tabular}

value-added taxes need to be distinguished from the ex-factory price of domestic products.

Due to lack of adequate data, we are unable to provide an overall measurement of the full range of non-tariff protection for traded textile products. However, an approximate calculation can be made of the range of non-tariff protection by selecting a typical commodity for comparison.

It is clear that the range of non-tariff protection is of negative value (Table 8.5). In the case of a general transaction for an imported assignment of products, due to the presence of high tariff protection, the domestic prices of home commodities retain price competitiveness even in the absence of non-tariff protection, whereas if the import pattern shifts to the processing trade the import tariff rate becomes zero. In this case, the imported commodities assume price competitiveness, and domestic commodities need to be protected by non-tariff measures. According to the data in Table 8.5, in 1994, the average non-tariff protection for selected Chinese textile products was about 23.1 per cent.

\section{THE IMPACT OF TRADE LIBERALISATION IN BOTH SECTORS ON THE CHINESE ECONOMY}

THE COSTS OF AUTOMOBILE TRADE PROTECTION AND THE IMPACTS OF LOWERED TARIFFS ON THE NATIONAL ECONOMY

Theoretically, implementation of automobile industry trade protection would have several direct effects, including 
- raising the price of imported automobiles, thus sparking a price rise on the domestic automobile market

- stimulating domestic automobile production and restricting domestic market demand for automobiles because of the rise in prices, resulting in a reduction in the import volume of automobiles

- increasing China's fiscal revenue through the tariffs levied on imported automobiles and their components.

According to this analysis, three formulae must be used to calculate the impacts of automobile trade protection

- imported automobile sales price $=\mathrm{fl}$ (level of automobile trade protection)

- automobile import volume $=\mathfrak{f 2}$ (imported automobile sales price, domestic demand)

- domestic automobile output $=\mathrm{f3}$ (imported automobile sales price, domestic demand).

Unlike taxation protection - the main component of which is tariff protection (rises in tariffs themselves and in other taxes resulting from the tariff)- the major components of non-taxation protection are regulations and measures restricting imports. These changes are comparatively frequent and irregular and, as a result, it is difficult to quantify their real protection effect. At the same time, tariff protection has the same effect as non-tariff protection from the perspective of quantity. When we consider the impact trade protection has on other components - that is, tariff and non-tariff measures - the quantity of imported automobiles is restricted by influencing the price of imported automobiles. In this sense, an estimation of the impact on import volume and the national economy exerted by import price variations due to tariff changes may likewise be applied to an analysis of the impact of non-tariff measures that cause the same import price change. Therefore, with respect to the formulae above, we will replace all trade protection measures with tariff protection. But as trade systems and channels differ and there still exist some tariff-exemption and tariff-reduction measures in the field of automobile imports, the actual applied tariff rate (automobile tariff volume/cost of automobile imports) is lower than the nominal tariff rate in the automobile trade. The important factor in the automobile import trade is the actual applied tariff rate, so it is more reasonable to adopt the actual applied tariff rate in our study. However, as data on tariffs for automobile imports in recent years are unobtainable, we tentatively adopt the applied tariff rates of the total import trade instead of the applied tariff rate in the automobile trade in the following analysis. This is because the applied tariff rate for automobile imports is a linear function of the applied tariff rate for the total import trade provided that tariff and import structures remain comparatively stable. That is,

applied tariff rate of automobiles $=\mathrm{a} \times$ average applied tariff rate of total import trade (a being a constant). 
Therefore, the applied tariff rate for the total import trade can take the place of the applied tariff rate for automobiles when we study the relative influence that variations on the applied automobile tariff rate exert on other aspects (elasticity analysis).

A further consideration is that domestic demand for automobiles in the above formulae is jointly influenced by domestic investment in fixed assets and domestic commodity prices. On the basis of the above analysis, let us suppose that

$\mathrm{FAD}=$ nominal domestic investment in fixed assets

$\mathrm{OPR}=$ domestic commodity price indices

$\mathrm{RTF}=$ applied tariff rate of the total import trade

$\mathrm{CARQ}=$ automobile import volume

CARDP $=$ domestic automobile production output

$\mathrm{CARG}=\mathrm{ACRQ}+\mathrm{CARDP}=$ domestic automobile supply volume

By using 1983-94 data and regression technology, we obtain the following formulae

$$
\begin{aligned}
\log (\text { cardp })= & 0.99219 \times \log (F A D / O P R)+0.34687 \times \log (1+\mathrm{RTF})+8.847 \\
& \left(\mathrm{R}^{2}=0.96 \quad \mathrm{DW}=1.97\right) \\
\log (\mathrm{carg})= & 0.00107 \times \mathrm{W}(\mathrm{FAD} / \mathrm{OPR})-0.66212 \times \log (1+\mathrm{RTF})+14.7205 \\
& \left(\mathrm{R}^{2}=0.71 \quad \mathrm{DW}=2.38\right)
\end{aligned}
$$

Here $\mathrm{W}$ (FAD/OPR) is the variation rate of FAD/OPR.

In what follows, the above formulae are employed to study the influence on other aspects, of variations in the tariff rate. Estimations using the data of the past few years yield

average nominal tariff rate from 35.9 per cent $\rightarrow 0$, then RTF from 2.7 per cent $\rightarrow 0$

and automobile import volume, automobile production output and domestic automobile supply volume are as in Table 8.6.

The above suppositions lead to the conclusion that the actual executive tariff rates for automobile trade and total trade fluctuate in the same manner. This being so, we can work out the effect on producer surplus, consumer surplus, efficiency gain and the actual executive tariff revenue in the light of trade liberalisation.

Producer Surplus Variation $(\triangle \mathrm{PS} 1)=0.5 \times(\mathrm{P} 1-\mathrm{P} 0) \times(\mathrm{Q} 1+\mathrm{Q} 2)$

Consumer Surplus Variation $(\Delta \mathrm{CS} 1)=-0.5 \times(\mathrm{P} 1-\mathrm{P} 0) \times(\mathrm{D} 1+\mathrm{D} 0)$

(Efficiency gain) $\mathrm{EG}=-0.5 \times(\mathrm{P} 1-\mathrm{P} 0) \times(\mathrm{IM} 0-\mathrm{IM} 1)$

The results of these estimations are detailed in Table 8.7. From these results, the nominal tariff rate for China's total trade was 35.9 per cent in 1995 . Given 
that the actual tariff rate is 2.7 per cent, domestic automobile enterprises raked in earnings of 2.458 billion yuan from the price rises in automobiles and the expansion of domestic automobile production that resulted from automobile trade protection. Concurrently, the price rise resulted in a loss to consumers of 2.761 billion yuan, meaning that automobile trade protection leads to a net welfare loss of 303 million yuan. In the same way, the net losses of automobile trade protection in the light of other schemes can also be calculated.

Table 8.6 Effect of tariff changes on automobile imports and domestic supply under different schemes

\begin{tabular}{cccccccccc}
\hline Scheme & $\begin{array}{c}\text { Nominal } \\
\text { tariff }\end{array}$ & $\begin{array}{c}\text { Real } \\
\text { applied } \\
\text { tariff } \\
(\%)\end{array}$ & $\begin{array}{c}\text { Auto } \\
\text { import }\end{array}$ & $\begin{array}{r}\text { Rate of } \\
\text { change }\end{array}$ & $\begin{array}{c}\text { Domestic } \\
\text { made } \\
\text { autos } \\
\text { (units) }\end{array}$ & $\begin{array}{c}\text { Rate } \\
\text { of } \\
\text { change } \\
(\%)\end{array}$ & $\begin{array}{c}\text { Domestic } \\
\text { supply }\end{array}$ & $\begin{array}{c}\text { Rate } \\
\text { of } \\
\text { change } \\
(\%)\end{array}$ \\
\hline $\begin{array}{c}\text { Standard } \\
\text { value }\end{array}$ & 35.9 & 2.7 & 157378 & $\ldots$ & 1452697 & $\ldots$ & 1610075 & \\
Scheme 1 & 23.0 & 1.725 & 172315 & 9.5 & 1447903 & -0.33 & 1620218 & 0.63 \\
Scheme 2 & 15.0 & 1.125 & 181339 & 15.2 & 1444998 & -0.53 & 1626337 & 1.01 \\
Scheme 3 & 5.0 & 0.375 & 192860 & 22.5 & 1441366 & -0.78 & 1634226 & 1.50 \\
Scheme 4 & - & - & 198613 & 26.2 & 1439477 & -0.91 & 1638090 & 1.74
\end{tabular}

Note: The change in auto sale prices is calculated on the basis of after-tariff sale prices of autos compared with CIF prices.

Source: Author's calculations.

Table 8.7 Cost of automobile trade protection under different schemes

\begin{tabular}{|c|c|c|c|c|c|c|c|c|}
\hline Scheme & $\begin{array}{l}\text { Nominal } \\
\text { tariff }\end{array}$ & $\begin{array}{c}\text { Real } \\
\text { applied } \\
\text { tariff } \\
(\%)\end{array}$ & $\begin{array}{l}\text { Auto } \\
\text { import } \\
(\%)\end{array}$ & $\begin{array}{c}\text { Domestic } \\
\text { output } \\
\text { (units) }\end{array}$ & $\begin{array}{c}\text { Change in } \\
\text { auto sale } \\
\text { price } \\
(\%)\end{array}$ & $\begin{array}{l}\text { Change } \\
\text { in } \\
\text { producer } \\
\text { surplus } \\
\text { (RMB } \\
100 \mathrm{~m} \text { ) }\end{array}$ & $\begin{array}{c}\text { Efficiency } \\
\text { gain } \\
\text { (RMB } \\
100 \mathrm{~m})\end{array}$ & $\begin{array}{l}\text { Change } \\
\text { in } \\
\text { consumer } \\
\text { surplus } \\
\text { (RMB } \\
100 \mathrm{~m} \text { ) }\end{array}$ \\
\hline $\begin{array}{l}\text { Standard } \\
\text { value }\end{array}$ & - & - & 198613 & 1439477 & .. & .. & .. & .. \\
\hline Scheme 1 & 35.9 & 2.7 & 157378 & 1452697 & 17.5 & 24.58 & -0.35 & -27.61 \\
\hline Scheme 2 & 23.0 & 1.725 & 172315 & 1447903 & 11.4 & 15.99 & -0.15 & -18.04 \\
\hline Scheme 3 & 15.0 & 1.125 & 181339 & 1444998 & 8.1 & 11.35 & -0.07 & -12.84 \\
\hline Scheme 4 & 5.0 & 0.375 & 192860 & 1441366 & 2.4 & 3.36 & -0.00 & -3.81 \\
\hline 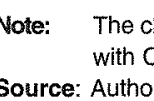 & $\begin{array}{l}\text { hange in au } \\
\text { IF prices. }\end{array}$ & sale $p$ & es is calcu & ated on th & asis of aft & tariff sale pr & rices of auto & tos compared \\
\hline
\end{tabular}




\section{ESTIMATION OF THE IMPACT OF TEXTILE TRADE PROTECTION ONTHE CHINESE ECONOMY}

MEASURING PRICE ELASTICITY OF DEMAND AND SUPPLY FOR TEXTILE PRODUCTS

The estimation focuses on the main products of the textile industry, divided into three groups

- textile fibres, including various kinds of yarn such as silk, wool and some chemical fibres

- textile fabrics, including chemical fibre cloth, wool fabrics and silk fabrics

- garments, including various kinds of garments, handkerchiefs, silk scarves and gloves.

By using time-series data from 1981 to 1993 , we can generate econometric equations concerning domestic output and the total quantity of demand for the abovementioned three textile products.

- Home production equation for textile fibre

$$
\begin{aligned}
& \text { LOG }(\text { GP01 })=0.34863 \text { LOG }(\text { GDPI })+0.48088 \text { LOG }((1+\text { RTF }) \times \text { PIMM }) \\
& \quad-0.09819 D 84+4.3140) \\
& \text { RSQ }=0.9655 \quad \text { DW }=1.3838
\end{aligned}
$$

- Equation of total demand for textile fibre

$$
\begin{aligned}
& \text { LOG }(\text { DP01 + IMP1/(PIMM } \times 3.14))=0.74151 \mathrm{LOG}(\mathrm{GDPI})- \\
& 0.62299 \operatorname{LOG}(1+\mathrm{RTF}) \quad+4.59209 \\
& \mathrm{RSQ}=0.9774 \quad \mathrm{DW}=1.9183
\end{aligned}
$$

- Home production equation for textile fabric

$$
\begin{aligned}
\text { LOG }(\mathrm{DP} 02) & =0.24483 \mathrm{LOG}(\mathrm{GDPI})+0.4923 \mathrm{LOG}((1+\mathrm{RTF}) \times \mathrm{PIMM})+6.28265 \\
\mathrm{RSQ} & =0.9266 \mathrm{DW}=2.6183
\end{aligned}
$$

- Total demand equation for textile fabric

$$
\begin{aligned}
\text { LOG }(\text { DP02 }+ \text { IMPZ/(PIMM } \times 2.861))=0.36245 \text { LOG }(\text { GDPI })- & \\
& 1.54526 \mathrm{LOG}(1+\text { RTF })+8.06926 \\
\text { RSQ }= & 0.9804 \quad \text { DW }=2.4216
\end{aligned}
$$

- Home production equation for garment

$$
\begin{aligned}
\text { LOG }(\mathrm{DP} 03)=1.32197 \mathrm{LOG}+1.04359 \mathrm{LOG}((1+\mathrm{RTF}) \times \mathrm{PIMM}) & \\
& -2.45408 \mathrm{D} 84-4.16089 \\
\mathrm{RSQ}= & 0.9832 \quad \mathrm{DW}=1.652
\end{aligned}
$$

- Total demand equation for garment

$$
\begin{aligned}
& \text { LOG }(\mathrm{DP03}+\mathrm{IMP} 3 /(\mathrm{PIMM} \times 4.04))=0.9169 \mathrm{LOG}(\mathrm{SQTC})-4.92151 \mathrm{LOG} \\
& (1+\mathrm{RTF})-2.20964 \mathrm{D} 84-4.03162 \\
& \mathrm{RSQ}= \\
& 0.9884 \quad \mathrm{DW}=1.9924
\end{aligned}
$$


In the above equations,

GDPI $=$ actual increase index of the fixed base for GDP

$\mathrm{RTFI}=$ applied and average tariff rates for the total amount of imported products

PIMM $=$ CIF price index for the total amount of imported products

DPOI $=$ domestic output for textiles under category $i(i=1,2,3)$

$\mathrm{IMPi}=$ imported amount for textiles under category $\mathrm{i}(\mathrm{i}=1,2,3)$

$\mathrm{SQTC}=$ total sales amount of garments on the domestic market.

From the previous part of the analysis, $(1+$ RTF $)$ shows the effect of the tariff applied on the sale price of imported products. Likewise, a change in the prices of imported products cause the price of the same kind of domestic products to change, and therefore the price of the product on the home market is the linear function for $(1+\mathrm{RTF})$.

According to these equations, we know that domestic output for the three categories of textile products is affected by the interaction between $(1+\mathrm{RTF})$ and the elasticity of domestic production, or $0.48088,0.49231$ and 1.04359, respectively. That is, for every percentage point increase in $(1+\mathrm{RTF})$, the domestic output of the three categories of textiles will increase by $0.48088,0.49231$ and 1.04359 percentage points, respectively. The elasticity

Table 8.8 Impact of tariff rate change on selected textile products' imports, domestic production and total demand

\begin{tabular}{lrrr}
\hline & $\begin{array}{c}\text { Actual value } \\
(1994,100 \mathrm{~m} \text { yuan })\end{array}$ & $\begin{array}{c}\text { Scenario I } \\
(\%)\end{array}$ & $\begin{array}{c}\text { Scenario II } \\
(\%)\end{array}$ \\
\hline Fibre & & & \\
$\quad$ Domestic production & 5441 & -0.401259 & -0.687873 \\
Imports & 755.7324 & 1.951597 & 3.345594 \\
Total demand & 6226.88 & 1.550337 & 2.657721 \\
Fabric & & & \\
Domestic production & 23754.12 & -0.891894 & -1.528962 \\
Imports & 2373.076 & 12.45764 & 21.35596 \\
Total demand & 48804.75 & 11.56574 & 19.82699 \\
Garments & & & -1.75 \\
Domestic production & 6367.82 & -1.02 & 10.15 \\
Imports & 126.24 & 5.92 & 8.4 \\
Total demand & 6494.06 & 4.9 & \\
& & & \\
Source: Author's calculations. & & & \\
\hline
\end{tabular}


Table 8.9 Effect of textile import protection

\begin{tabular}{lrr}
\hline & RTF $=1.125 \%$ & \\
& & \\
Fibre & 190.42 & \\
Producer surplus & -568.01 & 451.57 \\
Consumer surplus & 23.54 & -1346.94 \\
Efficiency gain & & 62.86 \\
Fabric & 736.34 & \\
Producer surplus & -1528.64 & 1781.50 \\
Consumer surplus & 74.09 & -3661.10 \\
Efficiency gain & & 178.78 \\
Garments & 280.12 & 674.90 \\
Producer surplus & -286.03 & -688.82 \\
Consumer surplus & 5.91 & 13.92 \\
Efficiency gain & & \\
Note: & & \\
Source: Author's calculations. & &
\end{tabular}

of demand in respect of changes in $(1+$ RTF $)$ for the three categories of textiles is $-0.62299,-1.54526$ and -4.92151 . In other words, for every percentage point increase in $(1+\mathrm{RTF})$, total demand for the three categories of textiles will drop by $0.62299,1.54526$ and 4.92151 percentage points, respectively.

\section{ESTIMATE OF THE IMPACT OF TRADE PROTECTION ON TEXTILE PRODUCTS}

Based on this analysis, the effect of changing the level of trade protection in the textile industry can be calculated. In view of the fact that the average nominal tariff rate governing total import trade is 35.9 per cent and the applied tariff rate is 2.7 per cent (RTF), if the average nominal tariff rate is cut from 35 per cent to $0, \mathrm{RTF}$ will go from 2.7 per cent $=>0$.

We calculate the effects of changing the tax rate on the import volume, domestic output and total demand of the three categories of textiles. The results of the calculations are shown in Table 8.8. Consequently, we can calculate the effects of trade protection on textiles imports, producer surplus, consumer surplus and the change in efficiency benefit.

Change in producer surplus $(\Delta \mathrm{PSi})=0.5 \times(\mathrm{Pi}-\mathrm{Poi}) \times(\mathrm{Qi}+\mathrm{Qoi})$

Change in consumer surplus $(\Delta \mathrm{CSi})=-0.5 \times(\mathrm{Pi}-\mathrm{Poi}) \times(\mathrm{Di}+\mathrm{Doi})$

Efficiency gain $(\mathrm{EG})=-0.5 \times(\mathrm{Pi} 0150-\mathrm{Poi}) \times(\mathrm{Moi}-\mathrm{Mi})$ 
In 1993, the nominal tariff rate for China's total import trade was 35.9 per cent, and the applied tariff rate-supposing the applied tariff rate for textile imports is similar to this - was 2.7 per cent (Table 8.9). In that case, the benefit gained by the three categories of textile enterprises that take advantage of the rise in price and the consequent expansion of production as a result of trade protection, is US\$451.57, US\$1781.50 and US\$674.90 million, respectively. However, the welfare losses to Chinese consumers, from the rise in prices, are US\$1346.94, US\$3661.10, and US\$688.82 million, respectively. Subsequently, the net loss resulting from trade protection for the three categories of textiles are US\$895.37, US\$1879.4, and US\$13.92 million, respectively, representing a total loss of $\$ 2788.69$ million.

\section{CONCLUSION}

The nominal reduction of tariffs will not have a significant influence on the Chinese economy in its early stages because of the large gap between nominal and applied tariff rates. This situation gives the Chinese government scope to push the process of tariff reduction and to ease non-tariff protection measures.

High tariff rates continue to be far more important than non-tariff measures in current automobile trade protection policies. In fact, the high rate of protection, allows the domestic automobile industry makes additional profits from other sectors of the domestic economy through pricing and distribution rents. Given that protection reduces competition, the original purpose of protecting the automobile industry has actually hindered the inflow of advanced technology and slowed the development of the domestic automobile industry. Furthermore, since the main automobile makers in China operate as joint ventures, the protection policy does not encourage foreign investors to use and improve technology.

Due to the low applied tariff rate and the dominance of the processing trade in the textile sector, there is little real protection in the domestic textile industry in China. It would be logical for China to select the textile sector as one of the early sectors for liberalisation.

In view of the larger price elasticity of demand in the textile industry, it is necessary to ensure, in the course of reducing the nominal tariff level, that the scope of applicable taxation be gradually expanded in case the applied trade protection decreases too rapidly and extensively. In other words, in the process of transforming the traditional industry to a modern industry, open competition is the key to improving efficiency, but it is necessary to maintain some protection in China for a period. The gradual reduction of trade protection is an inevitable trend, and domestic enterprises should make use of current opportunities to improve the competitiveness of their products to enable them to gain a favourable position in the future. 